\title{
Water fluoridation is a necessity- Believe it or not...
}

\author{
*Lahana Shrestha \\ Health and Safety Intern, University of Auckland, USA
}

Submission: May 11, 2017; Published: May 23, 2017

*Corresponding author: Lahana Shrestha, Health and Safety Intern, IPC Manager at SPN/MSI, University of Auckland, New Zealand, USA, Email: shrestha.lahana@gmail.com

\section{Opinion}

3Should the less fortunate people not be able to enjoy the benefits towards their oral health and jump in joy? Of course not. There have been ongoing debates on water fluoridation in New Zealand. Many are confused on deciding whether water fluoridation is a bane or a boon. It is clearly mentioned that everyone should be entitled to equal health rights in the Human Right Act 1993. It is a Government responsibility to ensure good health of the entire citizen. 27 out of 67 local authorities in New Zealand have water fluoridation which leaves behind approximately 1.4 million New Zealanders who are not able to access the fluoridated water [1].

The local Government is currently deciding on shifting the responsibility of providing fluoridated water to central authority, which can make a good impact in the society by reducing inequalities existing in New Zealand. We cannot neglect the issues that can develop due to unorganized decision. The burning issue of misusing tax payer's money in Hamilton could be taken as one out of many. The submission of local referendum can cost over $\$ 100,000$. Two referendum submitted by Hamilton in this case could have been used in other development activities or even in expansion of water fluoridation programs in areas where there is no fluoride. It was a waste of huge amount of money in making a decision and going back to correct it (Figures $1 \& 2)$.

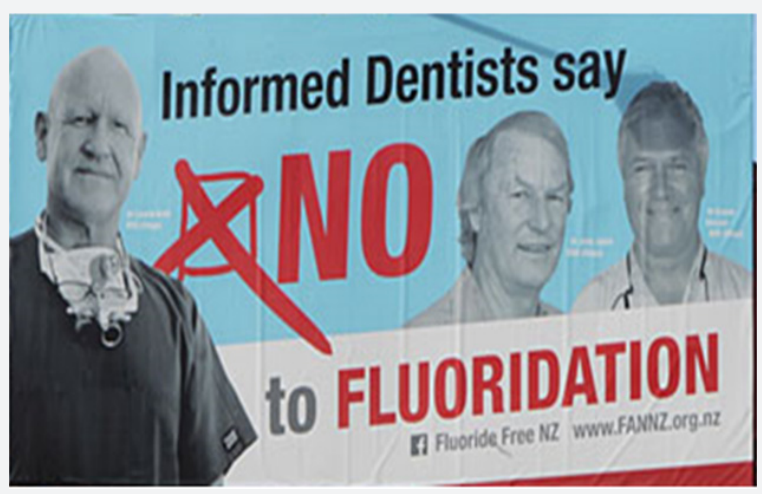

Figure 1: Dental Association identified the billboard as misleading.

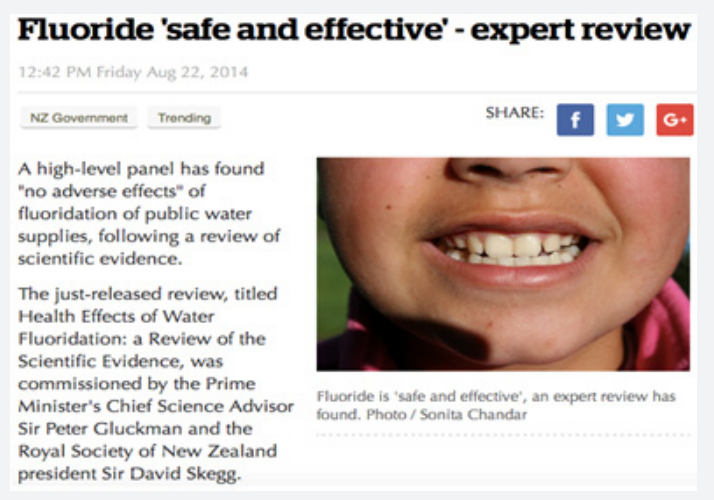

Figure 2: "Safe and Effective" as said by the experts.

\section{Should it be centralized?}

Water fluoridation is indeed the cheapest method to ensure equal supply of fluoride to people. It is an intervention for promotion of better dental care and reduction of tooth decay. The United States has often claimed use of fluoridated water to be the main reason behind declining tooth decay over 60 years [2]. This cannot be achieved with little effort. Community Water Fluoridation NZ has presented the comparison between cost per person for water fluoridation in a year which is 50 cents and cost per person for dental filling in a year which is $\$ 130$. There is a huge disparity in the incidence of tooth decay where Maori and Pacific children with lower socioeconomic status

are more likely to suffer from tooth decay due to lack of access to fluoridated water. If fluoridation is implemented from the central government, everyone will be benefitted from fluoride irrespective of their ethnicity and region. This will not only help in enhancing their quality of life by ensuring better oral health, but also hold on to the Treaty of Waitangi by providing equal health benefits to Maori.

\section{Benefits}

A study concluded that children under 5 years with access to fluoridated water were $30 \%$ less likely to have tooth decay than others who do not have access to fluoridated water. The percentage increased up to $40 \%$ among the children who 
were 12 years and under. This clearly shows the need of water fluoridation to ensure better oral health among children of all regions.

While talking about advantages of centralizing the responsibility, there are many small types of council that cannot afford the cost of water fluoridation, such as West Coast Regional with total population of 32,148 . Centralizing the responsibility can ensure equal access to all regardless of the region's economy. The Local Government also seems to be supporting the shift of responsibility towards the central government due to the expenses relating to water fluoridation at regional level. This was discussed in the conference held at Nelson regarding water fluoridation.
In the end, let's ask ourselves if the advantages of fluoride outweigh the risks. We should be able to decide if we want to spend hundreds of dollars on dental care or if we want to enjoy the benefits of fluoridated water and have a better oral health.

\section{References}

1. Mike Mather (2013) Anti-fluoride billboard divides dentists. Health global drug survey, USA.

2. Jamie Morton (2014) Fluoride 'safe and effective' - expert review. Nzherald, USA.

\section{Your next submission with Juniper Publishers} will reach you the below assets

- Quality Editorial service

- Swift Peer Review

- Reprints availability

- E-prints Service

- Manuscript Podcast for convenient understanding

- Global attainment for your research

- Manuscript accessibility in different formats

( Pdf, E-pub, Full Text, Audio)

- Unceasing customer service

Track the below URL for one-step submission https://juniperpublishers.com/online-submission.php 